\title{
IMPACT OF IRRIGATION WITH SALINE WATER ON GROWTH, QUALITY AND CHEMICAL COMPOSITION OF TALL FESCUE TURF (FESTUCA ARUNDINACEA SCHREB. VAR. FESTORINA)
}

\author{
S.M. Shahin ; Boshra A. El-Sayed ${ }^{* *}$ and H.F. El-Tayeb* \\ * Botanical Gardens Res. Dept., Hort. Res. Inst., ARC, Giza, Egypt. \\ ** Ornamental Plants and Landscape Gardening Res. Dept., Hort. Res. Inst., ARC, Giza, Egypt.
}

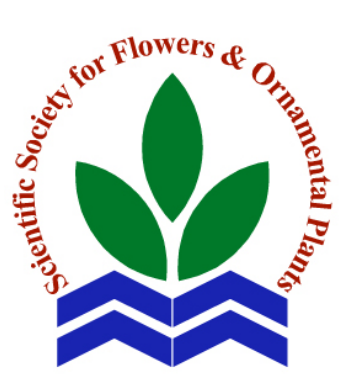

Scientific J. Flowers \& Ornamental Plants, 1(2):137-144 (2014).

Received:

$27 / 7 / 2014$

Revised by:

Prof. Dr. M.G. El-Torky, Alexandria Univ

Prof. Dr. Eman M. Abou El-Ghait, Banha Univ.

ABSTRACT: Two tray experiments were conducted in the open field at Orman Botanical Garden, Giza, Egypt during 2012/2013 and 2013/2014 seasons to study the effects of saline irrigation water prepared from $\mathrm{NaCl}$ and $\mathrm{CaCl}_{2}$ pure salts $(1: 1$, by weight) at the rates of $0,2000,4000,8000$ and $12000 \mathrm{ppm}$ on growth, quality and chemical composition of tall fescue (Festuca arundinacea Schreb. var. Festorina) plants cultivated by seeds in plastic trays $(51 \times 36 \times 10 \mathrm{~cm})$ filled with about $15 \mathrm{~kg}$ of loamy soil/ tray at the rate of $5 \mathrm{~g}$ seeds/tray.

The obtained results in both seasons indicated that salinity of irrigation water up to $4000 \mathrm{ppm}$ had no deleterious effects on plant height, density $\%$ and fresh and dry weights of herb and roots, except for $2000 \mathrm{ppm}$ salinity treatment which significantly improved vegetative and root growth of treated plants compared to the control. The opposite was right regarding 8000 and $12000 \mathrm{ppm}$ levels, which reduced all vegetative and root growth parameters, especially 12000 ppm level that gave the least means with significant differences when compared to control means in the two seasons. Moreover, chlorophylls $\mathrm{a}$ and $\mathrm{b}$ in the leaves and $\mathrm{N}$ and $\mathrm{P}$ content in the herb were decreased as the concentration of salinity was increased, while the contents of carotenoides, $\mathrm{K}, \mathrm{Na}, \mathrm{Cl}$ and the free amino acid proline were progressively increased with increasing salinity level.

According to these results, it could be concluded that Festuca arundinacea Schreb. var. Festorina turf can relatively tolerate salinity of irrigation water up to $8000 \mathrm{ppm}$ with the least harmful effects.

Key words: Festuca arundinacea, irrigation, saline water, salinity, $\mathrm{NaCl}, \mathrm{CaCl}_{2}$.

\section{INTRODUCTION}

Tall fescue is a heat, drought and wear tolerant grass that belongs to the Family Gramineae. Its sward is dense, but because of its coarse leaf texture, not very fine. It tolerates soils with low fertility and can also stand submersions. It is used on sports field, road sides, waterways, airfields, race courses and low maintenance areas. Because of its deep root system, tall fescue is especially suited for slope stabilization (Plain, 1985).
Festorina is a dense tillering, bright green variety that excels under warm and dry conditions. It shows a very good disease resistance and a very good resistance to wear and tear (Huxley et al., 1992).

Increasing need for salt-tolerant turf grasses is still continuous due to population growth in arid and semi-arid regions where potable water is limited and the underground or other water sources are salty. However, salinity may cause some harms for grasses, as those indicated by Mansour and Hussein 


\section{S.M. Shahin et al.}

(2002) who found that increasing salinity of irrigation water up to $6000 \mathrm{ppm}$ reduced growth, coverage, height and clippings fresh and dry weights of Tifway grass, especially when grown in sand. Chlorophylls, carotenoides and total carbohydrates were also decreased, while growing this type of turf in clay increased $\mathrm{Na}, \mathrm{Ca}$ and $\mathrm{Cl}$ content in the herb. Similar observations were also recorded by Peacock et al. (2004) on Tifway, Lee et al. (2004) on 4 bermudagrass cultivars, Adavi et al., (2006) and AbdelFattah et al. (2008) on Tifway, as they all reported that salinity of irrigation water declined growth, density and root length, beside yellowing or necrosis of the leaves.

On the other hand, Shahin (1990) noticed that top growth of bermudagrass was progressively increased with raising salinity level. Also, chlorophyll a and carotenoides content was increased by increasing salinity level up to $10000 \mathrm{ppm}$, while chlorophyll b content was decreased. An opposite trend was observed with ryegrass. Likewise, Pessarakli and Touchane (2006) mentioned that shoot and root lengths of Tifway 419 and seashore paspalum were stimulated at the low levels of $\mathrm{NaCl}$ (5000 and 10000 ppm), but substantially decreased at the high levels (20000 and $30000 \mathrm{ppm}$ ). As the exposure time to salt stress progressed, shoot and root fresh and dry weights were severly affected than shoot and root lengths. Tifway 419 was more affected than paspalum under any level of $\mathrm{NaCl}$ application. Uptake of $\mathrm{Na}$ and $\mathrm{Cl}$ was increased, whereas $\mathrm{K}$ uptake was decreased.

Table a. Some physical and chemical properties of the loamy soil used in 2012/13 and 2013/14 seasons.

\begin{tabular}{|c|c|c|c|c|c|c|c|c|c|c|c|c|c|c|}
\hline \multirow{2}{*}{ Season } & \multicolumn{4}{|c|}{$\begin{array}{l}\text { Particle size distribution } \\
(\%)\end{array}$} & \multirow{2}{*}{ S.P. } & \multirow{2}{*}{$\begin{array}{c}\text { EC } \\
(\mathrm{dS} / \mathrm{m})\end{array}$} & \multirow{2}{*}{$\mathbf{p H}$} & \multicolumn{4}{|c|}{ Cations (meq/L) } & \multicolumn{3}{|c|}{ Anions (meq/L) } \\
\hline & $\begin{array}{c}\text { Coarse } \\
\text { sand }\end{array}$ & $\begin{array}{l}\text { Fine } \\
\text { sand }\end{array}$ & Silt & Clay & & & & $\mathbf{C a}^{++}$ & $\mathbf{M g}^{++}$ & $\mathbf{N a}^{+}$ & $\mathbf{K}^{+}$ & $\mathrm{HCO}_{3}^{--}$ & $\mathrm{Cl}^{-}$ & $\mathrm{SO}_{4}^{--}$ \\
\hline $2012 / 13$ & 10.18 & 46.17 & 19.53 & 24.12 & 35.00 & 3.36 & 8.09 & 17.50 & 9.42 & 20.00 & 0.79 & 3.80 & 10.00 & 33.91 \\
\hline $2013 / 14$ & 10.30 & 46.54 & 18.88 & 24.28 & 33.10 & 3.51 & 7.90 & 18.00 & 8.95 & 20.50 & 0.85 & 3.65 & 10.20 & 34.45 \\
\hline
\end{tabular}

$\mathrm{NaCl}$ salt was mixed well with $\mathrm{CaCl}_{2}$ salt at the ratio of $1: 1$, by weight. Saline water was then prepared from the salts mixture at the rates of $0,2000,4000,8000$
This research aims to determine the effect of saline water on growth behaviour and chemical composition of tall fescue grass under environmental conditions of the Great Cairo Governorate.

\section{MATERIALS AND METHODS}

A set of tray experiments was performed in the open field at Orman Botanical Garden, Giza, Egypt during the two consecutive seasons of 2012/2013 and 2013/2014 to find out the effects of saline irrigation water at various concentrations on growth performance, quality and active constituents in herb of tall fescue plants.

So, seeds of tall fescue (Festuca arundinacea Schreb. var. Festorina, imported from D.J. Van Der Have Co., P.O.B.1, 4420AA Kapelle, Netherlands "500-510 seeds/g") were sown on October, $15^{\text {th }}$ for the two seasons in trays $(51 \times 36 \times$ $10 \mathrm{~cm}$ ) filled with about $15 \mathrm{~kg}$ of loamy soil at the rate of $5 \mathrm{~g}$ seeds/tray. The physical and chemical properties of the used soil in both seasons are shown in Table (a). The seeds were regularly scattered on the surface of the same used soil and finally pressed with a flat and smooth piece of wood for more contact with the soil. After sowing, the trays were daily sprayed with fresh water (about 350 $\mathrm{ml} /$ tray) to wet only the zone in which seeds are imbedded using a watering cane with fine pores until germination, which was completely established within 12 days. trays, then covered with a thin layer of the

and $12000 \mathrm{ppm}$. Afterwards, the trays were irrigated with $1.5 \mathrm{~L}$ of the previous saline water concentrations per tray, twice a week until the termination of each season on April, 
$15^{\text {th }}$. In addition, the control plants continued to be irrigated with fresh water.

After two months from sowing date (at December, $\left.15^{\text {th }}\right)$, the first cut was handly done with a very sharp stainless steel shear leaving stubbles with $3 \mathrm{~cm}$ long. Other four cuts were carried out monthly thereafter. Each treatment was replicated 3 times, as each replicate contained 3 trays, in a complete randomized design (Mead et al., 1993).

Before each cut, mean plant height $(\mathrm{cm})$ was recorded, while density \% (Mahdi, 1953 ) and fresh and dry weights of clippings (g) of the resulted clippings after mowing each tray were determined after each cut.

In fresh leaf samples taken from the first, third and fifth cuts, photosynthetic pigments content (Chlorophyll a, b and carotenoides, $\mathrm{mg} / \mathrm{g} \mathrm{F}$.W.) was measured according to the method of Moran (1982), whereas in dry samples taken from the herb of the three previously mentioned cuts, the percentages of N (Pregl, 1945), P (Watanabe and Olsen, 1965), K (Jackson, 1973) and the content of $\mathrm{Na}$ and $\mathrm{Cl}$ as mg/g D.W. (Jackson, 1973) were determined. The content of free amino acid proline $(\mu \mathrm{g} / \mathrm{ml})$ was also evaluated by the method described by Bates et al. (1973).

At the end of each season, root samples from a known volume $(10 \times 10 \times 10 \mathrm{~cm})$ of soil subjected to the different salinity treatments applied in such work were gently lifted and washed well with tap water to evaluate their fresh and dry weights (g). Data were then tabulated, and the morphological ones were statistically analyzed according to SAS Institute Program (1994) using Duncan's Multiple Range Test (Duncan, 1955) for verifying the significancy level among various treatments.

\section{Results and Discussion}

\section{Effect of saline irrigation water on:}

\section{1- Vegetative and root growth parameters:}

From data averaged in Tables $(1,2,3$ and 4), it could be concluded that salinity of irrigation water up to $4000 \mathrm{ppm}$ had no deleterious effect on plant height $(\mathrm{cm})$, density (\%) and herb fresh and dry weights $(\mathrm{g})$, as the means of these parameters were closely near to those of control with nonsignificant differences in most cases of the two seasons in the five cuts carried out through the growing season, except for 2000 ppm concentration which improved vegetative growth of salinized plants with significant differences over control, especially at the three last cuts. In addition, the utmost high dry weight of the herb in the five cuts in the two seasons was recorded by $2000 \mathrm{ppm}$ salinity treatment. The opposite was the right concerning 8000 and 12000 ppm levels, as they were significantly reduced all vegetative growth traits, especially 12000 ppm level which gave the least means in both seasons.

The favourable effects of low salinity levels on growth and density of tall fescue grass are unexpected results, and deserve further investigation. However, no-one has offered an acceptable explanation of this phenomenon, but it coincides with the results attained by Shahin (1990) on bermudagrass and Pessarakli and Touchane (2006) who mentioned that high $\mathrm{Na}$ level in the outer medium enhance cell expansion and growth of Tifway 419 and seashore paspalum. On the other hand, the reduction of growth due to high salinity concentrations may be attributed to a decrease in all volume at a constant cell number caused by salinity (Advai et al., 2006). Likewise, Pessarakli and Touchane (2006) postulated that mechanism of salt may result in cell division inhibitory and hence, reduces the rate of plant development. However, Jou et al. (2006) indicated that ATpase participates in the endoplasmic reticulum Golgi mediated protein sorting machinery for both housekeeping function and compartmentalization of excess $\mathrm{Na}^{+}$under high salinity. On the same line, were those results revealed by Shahin (1990) on ryegrass, Lee et al. (2004) on 4 bermudagrass cultivars and Adavi et al. (2006) and Abdel-Fattah et al. (2008) on Tifway. 
Table 1. Effect of saline water treatments on plant height $(\mathrm{cm})$ of Festuca arundinacea Schreb. var. Festorina clippings during 2012/13 and 2013/14 seasons.

\begin{tabular}{lcccccccccc}
\hline $\begin{array}{l}\text { Saline water } \\
\text { concentration } \\
\text { (ppm) }\end{array}$ & \multicolumn{4}{c}{ First season: $\mathbf{2 0 1 2 / 1 3}$} & \multicolumn{5}{c}{ Second season: 2013/14 } \\
\hline $\mathbf{0}$ & $\mathbf{1}^{\text {st }}$ cut & $\mathbf{2}^{\text {nd }} \mathbf{c u t}$ & $\mathbf{3}^{\text {rd }} \mathbf{c u t}$ & $\mathbf{4}^{\text {th }}$ cut & $\mathbf{5}^{\text {th }}$ cut & $\mathbf{1}^{\text {st }}$ cut & $\mathbf{2}^{\text {nd }}$ cut & $\mathbf{3}^{\text {rd }}$ cut & $\mathbf{4}^{\text {th }}$ cut & $\mathbf{5}^{\text {th }}$ cut \\
$\mathbf{2 0 0 0}$ & $16.7 \mathrm{a}$ & $14.0 \mathrm{a}$ & $13.0 \mathrm{~b}$ & $11.5 \mathrm{~b}$ & $9.3 \mathrm{a}$ & $15.9 \mathrm{a}$ & $14.6 \mathrm{a}$ & $13.2 \mathrm{~b}$ & $11.0 \mathrm{~b}$ & $9.5 \mathrm{a}$ \\
$\mathbf{4 0 0 0}$ & $17.0 \mathrm{a}$ & $13.3 \mathrm{a}$ & $15.2 \mathrm{a}$ & $13.2 \mathrm{a}$ & $8.7 \mathrm{ab}$ & $16.3 \mathrm{a}$ & $13.8 \mathrm{a}$ & $14.6 \mathrm{a}$ & $12.4 \mathrm{a}$ & $8.8 \mathrm{ab}$ \\
$\mathbf{8 0 0 0}$ & $16.1 \mathrm{a}$ & $13.0 \mathrm{ab}$ & $13.5 \mathrm{~b}$ & $12.5 \mathrm{ab}$ & $8.3 \mathrm{~b}$ & $15.4 \mathrm{a}$ & $13.3 \mathrm{ab}$ & $12.9 \mathrm{~b}$ & $12.6 \mathrm{a}$ & $8.3 \mathrm{~b}$ \\
$\mathbf{1 2 0 0 0}$ & $15.3 \mathrm{~b}$ & $12.6 \mathrm{~b}$ & $12.4 \mathrm{cb}$ & $10.9 \mathrm{c}$ & $7.8 \mathrm{cb}$ & $14.6 \mathrm{~b}$ & $13.1 \mathrm{~b}$ & $12.0 \mathrm{c}$ & $10.3 \mathrm{cb}$ & $7.5 \mathrm{c}$ \\
\hline
\end{tabular}

* Means within a column having the same letters are not significantly different according to Duncan's Multiple Range Test (DMRT, 1955) at 5\% level.

Table 2. Effect of saline water treatments on density (\%) of Festuca arundinacea Schreb. var. Festorina clippings during 2012/13 and 2013/14 seasons.

\begin{tabular}{lcccccccccc}
\hline $\begin{array}{l}\text { Saline water } \\
\text { concentration } \\
\text { (ppm) }\end{array}$ & \multicolumn{4}{c}{ First season: 2012/13 } & \multicolumn{4}{c}{ Second season: 2013/14 } \\
\hline $\mathbf{0}$ & $\mathbf{1}^{\text {st }}$ cut & $\mathbf{2}^{\text {nd }} \mathbf{c u t}$ & $\mathbf{3}^{\text {rd }}$ cut & $\mathbf{4}^{\text {th }}$ cut & $\mathbf{5}^{\text {th }}$ cut & $\mathbf{1}^{\text {st }}$ cut & $\mathbf{2}^{\text {nd }}$ cut & $\mathbf{3}^{\text {rd }}$ cut & $\mathbf{4}^{\text {th }}$ cut & $\mathbf{5}^{\text {th }}$ cut \\
$\mathbf{2 0 0 0}$ & $78.0 \mathrm{a}$ & $88.3 \mathrm{a}$ & $90.7 \mathrm{~b}$ & $93.4 \mathrm{a}$ & $87.3 \mathrm{ab}$ & $84.3 \mathrm{a}$ & $92.4 \mathrm{a}$ & $94.5 \mathrm{~b}$ & $96.3 \mathrm{a}$ & $89.9 \mathrm{ab}$ \\
$\mathbf{4 0 0 0}$ & $76.9 \mathrm{a}$ & $89.0 \mathrm{a}$ & $93.5 \mathrm{a}$ & $94.0 \mathrm{a}$ & $89.0 \mathrm{a}$ & $83.2 \mathrm{a}$ & $93.0 \mathrm{a}$ & $96.7 \mathrm{a}$ & $95.0 \mathrm{a}$ & $91.5 \mathrm{a}$ \\
$\mathbf{8 0 0 0}$ & $77.1 \mathrm{a}$ & $88.7 \mathrm{a}$ & $90.0 \mathrm{~b}$ & $86.5 \mathrm{~b}$ & $81.7 \mathrm{~b}$ & $83.0 \mathrm{a}$ & $93.2 \mathrm{a}$ & $93.8 \mathrm{bc}$ & $91.1 \mathrm{~b}$ & $83.4 \mathrm{~b}$ \\
$\mathbf{1 2 0 0 0}$ & $76.3 \mathrm{~b}$ & $85.4 \mathrm{~b}$ & $87.3 \mathrm{c}$ & $85.8 \mathrm{~b}$ & $80.8 \mathrm{c}$ & $82.1 \mathrm{~b}$ & $89.3 \mathrm{~b}$ & $91.7 \mathrm{c}$ & $89.0 \mathrm{cb}$ & $82.3 \mathrm{c}$ \\
\hline
\end{tabular}

* Means within a column having the same letters are not significantly different according to Duncan's Multiple Range Test (DMRT, 1955) at 5\% level.

Table 3. Effect of saline water treatments on fresh weight (g) of Festuca arundinacea Schreb. var. Festorina plants during 2012/13 and 2013/14 seasons.

\begin{tabular}{|c|c|c|c|c|c|c|c|c|c|c|}
\hline \multirow{2}{*}{$\begin{array}{l}\text { Saline water } \\
\text { concentration } \\
(\mathrm{ppm})\end{array}$} & \multicolumn{5}{|c|}{ First season: 2012/13 } & \multicolumn{5}{|c|}{ Second season: $2013 / 14$} \\
\hline & $1^{\text {st }}$ cut & $2^{\text {nd }}$ cut & $3^{\text {rd }}$ cut & $4^{\text {th }}$ cut & $5^{\text {th }}$ cut & $1^{\text {st }}$ cut & $2^{\text {nd }}$ cut & $3^{\text {rd }}$ cut & $4^{\text {th }} \mathrm{cut}$ & $5^{\text {th }}$ cut \\
\hline$\overline{0}$ & $125.3 \mathrm{ab}$ & $124.0 \mathrm{ab}$ & $134.3 b$ & $95.1 \mathrm{ab}$ & $66.3 \mathrm{ab}$ & $127.5 \mathrm{ab}$ & $129.0 \mathrm{a}$ & $131.5 b$ & $93.6 \mathrm{a}$ & $67.0 \mathrm{ab}$ \\
\hline 2000 & $130.2 \mathrm{a}$ & $128.3 \mathrm{a}$ & $146.4 \mathrm{a}$ & $98.2 \mathrm{a}$ & $68.0 \mathrm{a}$ & $132.3 \mathrm{a}$ & $123.3 b$ & $143.1 \mathrm{a}$ & $95.1 \mathrm{a}$ & $68.9 \mathrm{a}$ \\
\hline 4000 & $123.0 \mathrm{ab}$ & $112.9 b$ & $136.5 b$ & $96.0 \mathrm{ab}$ & $61.5 b$ & $125.1 \mathrm{ab}$ & $117.5 \mathrm{c}$ & $133.2 b$ & $93.8 \mathrm{a}$ & $62.4 \mathrm{~b}$ \\
\hline 8000 & $117.2 \mathrm{~b}$ & $98.6 c$ & $107.8 \mathrm{c}$ & $83.7 \mathrm{~b}$ & $58.9 \mathrm{c}$ & $119.3 b$ & $102.0 \mathrm{~d}$ & $106.0 \mathrm{c}$ & $82.3 b$ & $59.6 \mathrm{c}$ \\
\hline 12000 & $84.7 \mathrm{c}$ & $78.5 \mathrm{~d}$ & $88.0 \mathrm{~d}$ & $67.6 c$ & $50.7 \mathrm{~d}$ & $86.4 \mathrm{c}$ & $81.4 \mathrm{e}$ & $86.3 d$ & $66.4 \mathrm{c}$ & $51.5 \mathrm{~d}$ \\
\hline
\end{tabular}

* Means within a column having the same letters are not significantly different according to Duncan's Multiple Range Test (DMRT, 1955) at 5\% level.

Table 4. Effect of saline water treatments on dry weight (g) of Festuca arundinacea Schreb. var. Festorina plants during 2012/13 and 2013/14 seasons.

\begin{tabular}{|c|c|c|c|c|c|c|c|c|c|c|}
\hline \multirow{2}{*}{$\begin{array}{l}\text { Saline water } \\
\text { concentration } \\
(p p m)\end{array}$} & \multicolumn{5}{|c|}{ First season: 2012/13 } & \multicolumn{5}{|c|}{ Second season: $2013 / 14$} \\
\hline & $1^{\text {st }}$ cut & $2^{\text {nd }}$ cut & $3^{\text {rd }}$ cut & $4^{\text {th }}$ cut & $5^{\text {th }}$ cut & $1^{\text {st }}$ cut & $2^{\text {nd }}$ cut & $3^{\text {rd }}$ cut & $4^{\text {th }}$ cut & $5^{\text {th }}$ cut \\
\hline 0 & $18.5 b$ & $21.3 \mathrm{ab}$ & $23.1 \mathrm{~b}$ & $16.3 \mathrm{ab}$ & $11.2 \mathrm{ab}$ & $19.1 \mathrm{~b}$ & $22.0 \mathrm{ab}$ & $22.4 b$ & $15.8 \mathrm{ab}$ & $11.4 \mathrm{ab}$ \\
\hline 2000 & $20.9 \mathrm{a}$ & $23.0 \mathrm{a}$ & $26.3 \mathrm{a}$ & $17.5 \mathrm{a}$ & $12.4 \mathrm{a}$ & $21.5 \mathrm{a}$ & $23.7 \mathrm{a}$ & $25.1 \mathrm{a}$ & $17.0 \mathrm{a}$ & $12.5 \mathrm{a}$ \\
\hline 4000 & $17.8 \mathrm{bc}$ & $18.6 b$ & $23.4 \mathrm{~b}$ & $16.4 \mathrm{ab}$ & $10.7 b$ & $18.3 \mathrm{cb}$ & $19.2 b$ & $22.7 b$ & $15.9 \mathrm{ab}$ & $10.9 b$ \\
\hline 8000 & $16.7 \mathrm{c}$ & $14.1 \mathrm{c}$ & $15.5 \mathrm{c}$ & $12.0 \mathrm{~b}$ & $9.5 \mathrm{c}$ & $17.2 \mathrm{c}$ & $14.5 \mathrm{c}$ & $15.1 \mathrm{c}$ & $11.7 \mathrm{c}$ & $9.7 \mathrm{c}$ \\
\hline 12000 & $12.3 \mathrm{~d}$ & $11.4 \mathrm{~d}$ & $12.3 \mathrm{~d}$ & $9.5 \mathrm{c}$ & $7.3 \mathrm{~d}$ & $12.8 \mathrm{~d}$ & $11.8 \mathrm{~d}$ & $12.0 \mathrm{~d}$ & $9.2 \mathrm{~d}$ & $7.5 \mathrm{~d}$ \\
\hline
\end{tabular}

* Means within a column having the same letters are not significantly different according to Duncan's Multiple Range Test (DMRT, 1955) at 5\% level. 
A similar response occurred as well with respect to roots fresh and dry weights (g), as 2000 and 4000 ppm levels significantly improved these two characters, with the prevalence of 2000 ppm level, which recorded the heaviest roots fresh and dry weights comparing with control and other levels of salinity in the two seasons. On the other side, irrigation with saline water at 8000 and $12000 \mathrm{ppm}$ greatly decreased fresh and dry weights of the roots, especially the highest concentration that registered the lightest weights at all (Table, 5).

These results could be discussed and interpretted as done before in case of vegetative growth traits.

\section{2- Chemical Composition:}

Data in Tables (6, 7 and 8) showed that chlorophylls a and b content (mg/g F.W.) in the leaves and the percentages of $\mathrm{N}$ and $\mathrm{P}$ in the herb at the first, third and fifth cuts were gradually decreased as the concentration of saline water was increased with few exceptions, whereas the herb content of carotenoides (mg/g F.W.), K (\%), $\mathrm{Na}$ and $\mathrm{Cl}$ (mg/g D.W.), as well as proline $(\mu \mathrm{g} / \mathrm{ml})$ were progressively increased with increasing salinity level at the three mentioned cuts.

Increasing some constituents in the herb of salinized plants may be ascribed to that higher salt concentration in the soil solution usually leads to an increase in the uptake of some highly hydrophilic ions, e.g. $\mathrm{Na}$ or borate (Doak et al., 2005). Furthermore, Gilbert et al. (1998) suggested that accumulation of some amino acids and amids in the leaves of salinity-stressed plants may be due to de novo synthesis and not to be the result of degradation. In this regard, Barnett and Naylor (1966) found that free proline in the leaves of stressed bermudagrass plants was 10 to 125 times the value in control plants. Mengel and Kirkby (1979) indicated that proline accumulation (in the vacuoles and perhaps also in the cytoplasm of the cells) seems to occur strictly as a response to salt or water stress, and there is presently little evidence that species normally having high proline levels are any more tolerant to salt or water stress.

The aforementioned results, in general showed a similar trend to those obtained by Mansour and Hussein (2002) and Peacock et al. (2004) on Tifway, Pessarkli and Touchane (2006) on Tifway 419 and seashore paspalum and Abdel-Fattah et al. (2008) on Tifway Bermuda hybrid.

From the previous results, it could be concluded that Festuca arundinacea Schreb. var. Festorina can relatively tolerate irrigation with saline water up to $8000 \mathrm{ppm}$ with the least harmful effects.

\section{REFERENCES}

Abdel-Fattah, H. Gehan; El-Sayed, Boshra, A. and Shahin, S.M. (2008). The role of humic acid in reducing the harmful effect of irrigation with saline water on Tifway turf. J. Biol. Chem. \& Environ. Sci., 3(1):75-89.

Adavi, Z.; Razmajoo, K. and Mobli, M. (2006). Salinity tolerance of bermudagrass (Cynodon spp. L. C. Rich) cultivars and shoot $\mathrm{Na}, \mathrm{K}$ and $\mathrm{Cl}$ contents under a high saline environment. J. Hort. Sci. \& Biotech., 81(6):1074-1078.

Barnett, N.M. and Naylor, A.W. (1966). Amino acid and protein metabolism in bermudagrass during water stress. Plant Physiol., 44:1222-1230.

Bates, L.S.; Waldan, R.P. and Teare, L.D. (1973). Rapid determination of free proline under water stress studies. Plant and Soil., 39:205-207.

Doak, S.O.; Schmidt, R.E. and Ervin, E.H. (2005). Metabolic enhancer impact on creeping bentgrass leaf sodium and physiology under salinity. Inter. Turfgrass Soc. Res. J., 10:845-849.

Duncan, D.B. (1955). Multiple range and multiple F-tests. J. Biometrics, 11:1-42.

Gilbert, G.A.; Gadushi, M.V.; Wilson, C. and Madore, M.A. (1998). Amino acid accumulation in sink and source tissues of Coleus blumei Benth. during salinity 
Table 5. Effect of saline water treatments on roots fresh and dray weights (g) of Festuca arundinacea Schreb. var. Festorina plants during 2012/13 and 2013/14 seasons.

\begin{tabular}{|c|c|c|c|c|}
\hline \multirow{2}{*}{$\begin{array}{l}\text { Saline water } \\
\text { concentration } \\
\text { (ppm) }\end{array}$} & \multicolumn{2}{|c|}{ Roots F.W(g)/10 $\mathrm{cm}^{3}$ soil } & \multicolumn{2}{|c|}{ Roots D.W(g) $/ 10 \mathrm{~cm}^{3}$ soil } \\
\hline & $1^{\text {st }}$ season & $2^{\text {nd }}$ season & $1^{\text {st }}$ season & $2^{\text {nd }}$ season \\
\hline 0 & $16.8 \mathrm{c}$ & $17.0 \mathrm{c}$ & $7.6 \mathrm{cb}$ & $7.8 \mathrm{c}$ \\
\hline 2000 & $20.2 \mathrm{a}$ & $20.5 a$ & $9.1 \mathrm{a}$ & $9.4 \mathrm{a}$ \\
\hline 4000 & $18.3 b$ & $18.6 \mathrm{~b}$ & $8.3 b$ & $8.1 b$ \\
\hline 8000 & $13.2 \mathrm{~d}$ & $13.4 d$ & $5.8 \mathrm{c}$ & $6.0 \mathrm{~d}$ \\
\hline 12000 & $11.9 \mathrm{e}$ & $12.0 \mathrm{e}$ & $5.4 \mathrm{c}$ & $5.6 \mathrm{~d}$ \\
\hline
\end{tabular}

* Means within a column having the same letters are not significantly different according to Duncan's Multiple Range Test (DMRT, 1955) at 5\% level.

Table 6. Effect of saline water treatments on photosynthetic pigments content (mg/g F.W.) of Festuca arundinacea Schreb. var. Festorina plants during 2013/14 season.

\begin{tabular}{lccccccccc}
\hline $\begin{array}{l}\text { Saline water } \\
\text { concentration } \\
(\mathbf{p p m})\end{array}$ & \multicolumn{3}{c}{ Chlorophyll a } & \multicolumn{3}{c}{ Chlorophyll b } & \multicolumn{3}{c}{ Carotenoides } \\
& $\mathbf{1}^{\text {st }} \mathbf{c u t}$ & $\mathbf{3}^{\text {rd }} \mathbf{c u t}$ & $\mathbf{5}^{\text {th }} \mathbf{c u t}$ & $\mathbf{1}^{\text {st }}$ cut & $\mathbf{3}^{\text {rd }} \mathbf{c u t}$ & $\mathbf{5}^{\text {th }}$ cut & $\mathbf{1}^{\text {st }}$ cut & $\mathbf{3}^{\text {rd }}$ cut & $\mathbf{5}^{\text {th }}$ cut \\
\hline $\mathbf{0}$ & 1.90 & 1.78 & 1.81 & 0.41 & 0.36 & 0.30 & 0.88 & 1.16 & 1.04 \\
$\mathbf{2 0 0 0}$ & 1.81 & 1.46 & 1.93 & 0.44 & 0.41 & 0.33 & 0.94 & 1.19 & 1.07 \\
$\mathbf{4 0 0 0}$ & 1.82 & 1.13 & 1.43 & 0.42 & 0.34 & 0.30 & 0.99 & 1.23 & 1.06 \\
$\mathbf{8 0 0 0}$ & 1.69 & 1.26 & 1.39 & 0.38 & 0.35 & 0.31 & 1.09 & 1.21 & 1.10 \\
$\mathbf{1 2 0 0 0}$ & 1.50 & 1.20 & 1.20 & 0.38 & 0.33 & 0.27 & 1.18 & 1.25 & 1.18 \\
\hline
\end{tabular}

Table 7. Effect of saline water treatments on $N, P$ and $K$ percentages in the herb of Festuca arundinacea Schreb. var. Festorina plants during 2013/14 season.

\begin{tabular}{|c|c|c|c|c|c|c|c|c|c|}
\hline \multirow{2}{*}{$\begin{array}{l}\text { Saline water } \\
\text { concentration } \\
(\mathbf{p p m})\end{array}$} & \multicolumn{3}{|c|}{$\mathbf{N} \%$} & \multicolumn{3}{|c|}{ P \% } & \multicolumn{3}{|c|}{ K\% } \\
\hline & $1^{\text {st }}$ cut & $3^{\text {rd }}$ cut & $5^{\text {th }}$ cut & $1^{\text {st }}$ cut & $3^{\text {rd }}$ cut & $5^{\text {th }}$ cut & $\mathbf{1}^{\text {st }}$ cut & $3^{\text {rd }}$ cut & $5^{\text {th }}$ cut \\
\hline$\overline{0}$ & 1.96 & 2.14 & 1.70 & 0.50 & 0.43 & 0.29 & 1.63 & 1.76 & 1.68 \\
\hline 2000 & 1.38 & 1.30 & 1.31 & 0.53 & 0.38 & 0.26 & 1.82 & 2.00 & 2.10 \\
\hline 4000 & 1.43 & 1.21 & 1.12 & 0.41 & 0.33 & 0.21 & 1.90 & 2.12 & 2.36 \\
\hline 8000 & 1.36 & 1.08 & 1.03 & 0.41 & 0.30 & 0.14 & 1.99 & 2.11 & 2.50 \\
\hline 12000 & 1.33 & 1.00 & 0.96 & 0.40 & 0.30 & 0.11 & 2.11 & 2.30 & 2.69 \\
\hline
\end{tabular}

Table 8. Effect of saline water treatments on $\mathrm{Na}, \mathrm{Cl}$ and Proline content in the herb of Festuca arundinacea Schreb. var. Festorina plants during 2013/14 season.

\begin{tabular}{lcccccccccc}
\hline $\begin{array}{l}\text { Saline water } \\
\text { concentration } \\
\text { (ppm) }\end{array}$ & \multicolumn{2}{c}{$\mathbf{N a}(\mathbf{m g} / \mathbf{g}$ D.W.) } & \multicolumn{3}{c}{ Cl (mg/g D.W. } & \multicolumn{3}{c}{ Proline $(\mu \mathrm{g} / \mathbf{m l})$} \\
\hline $\mathbf{0}$ & $\mathbf{1}^{\text {st }}$ cut & $\mathbf{3}^{\text {rd }}$ cut & $\mathbf{5}^{\text {th }}$ cut & $\mathbf{1}^{\text {st }}$ cut & $\mathbf{3}^{\text {rd }}$ cut & $\mathbf{5}^{\text {th }}$ cut & $\mathbf{1}^{\text {st }}$ cut & $\mathbf{3}^{\text {rd }}$ cut & $\mathbf{5}^{\text {th }}$ cut \\
$\mathbf{2 0 0 0}$ & 1.05 & 1.36 & 1.33 & 1.10 & 1.26 & 1.34 & 0.051 & 0.058 & 0.054 \\
$\mathbf{4 0 0 0}$ & 1.71 & 2.08 & 2.81 & 1.49 & 1.67 & 1.97 & 0.065 & 0.079 & 0.112 \\
$\mathbf{8 0 0 0}$ & 1.90 & 2.47 & 3.00 & 1.63 & 1.88 & 2.58 & 0.083 & 0.103 & 0.158 \\
$\mathbf{1 2 0 0 0}$ & 2.10 & 3.10 & 3.38 & 2.18 & 2.61 & 3.50 & 0.136 & 0.156 & 0.193 \\
\hline
\end{tabular}


stress. J. Expermiental Botany, 49(318):107-114.

Huxley, A.; Griffiths, M. and Levy, M. (1992). The New Royal Horticultural Society Dictionary of Gardening. The Stockton Press, 257 Park Avenue South, New York, N.Y. 10010, U.S.A., Vol. 2, $747 \mathrm{pp}$.

Jackson, M.L. (1973). Soil Chemical Analysis. Prentice-Hall of India Private Ltd. M-97, New Delhi, India, 498 pp.

Jou, Y.; Chiang, C.; Jauh, G. and Yen, H.C. (2006). Functional characterization of ice plant SDKI, an AAA-type ATPase associated with the endoplasmic reticulum-Golgi network, and its role in adaptation to salt stress. Plant physiol., 141(1):135-146.

Lee, G.; Carrow, R.N. and Duncan, R.R. (2004). Salinity tolerance of selected seashore paspalums and bermudagrasses: root and verdure responses and criteria. HortScience, 39(5):1143-47.

Watanabe, F.S. and Olsen, S.R. (1965). Test of an ascorbic acid method for determining phosphorus in water and $\mathrm{NaHCO}_{3}$ extracts from soil. Soil Sci. Soc. Amer. J., 29(6):677-678.

Mahdi, M.Z. (1953). The Influence of Management on Botanical Composition and Quality of Turf. Ph.D. Thesis, Fac. Agric., California Univ., Los-Angeles, USA.

Mansour, H.A. and M.M. Hussein (2002). Tolerance of three turfgrasses grown in three types of soil to irrigation water salinity. Bull. Fac. Agric., Cairo Univ., 53(2):235-264.
Mead, R.; Curnow, R.N. and Harted, A.M. (1993). Statistical Methods in Agriculture and Experimental Biology. $2^{\text {nd }}$ Ed., Chapman \& Hall Ltd., London, 335 pp.

Mengel, K. and Kirkby, E.A. (1979). Principles of Plant Nutrition, $2^{\text {nd }} E d$. International Potash Inst., P.O.B. CH3048 Worblaufen, Bern, Switzerland, 593 pp.

Moran, R. (1982). Formula for determination of chlorophyllous pigment extracted with N, N-dimethyl formamide. Plant Physiol., 69: 1376-1381.

Peacock, C.H.; Lee, D.J.; Reynolds, W.C.; Gregg, J.P.; Cooper, R.J. and Bruneau, A.H. (2004). Effects of salinity on six bermudagrass turf cultivars. Acta Hort., 661:193-197.

Pessarakli, M. and Touchane, H. (2006). Growth responses of bermudagrass and seashore paspalum under various levels of sodium chloride stress. J. Food, Agric. and Environ., 4(3/4): 240-243.

Plain, R. (1985). The Master Gardener's Guide to Lawn Care. Salamander Books Ltd., Salamander House, 27 Old Gloucester St., London, UK., 77 pp.

Pregl, F. (1945). Quantitative Organic Micro-Analysis, $4^{\text {th }}$ Ed., J. and A. Churchill Ltd., London, P.:203-209.

SAS Institute Program (1994). SAS / STAT User's Guide: Statistics, Vers. 6.04, $4^{\text {th }}$ Ed., SAS Institute Inc., Cary, N.C., USA.

Shahin, S.M. (1990). Effect of Salinity on Growth and Constituents of Some Turfgrass Species. M.Sc. Thesis, Fac. Agric., Cairo Univ. 


\title{
S.M. Shahin et al.
}

تأثثير الري بالمياه المالحة على النمو، الجودة والتركيب الكيميائي لمسطح الفسكيو الطويل Festuca) arundinacea Schreb var. Festorina)

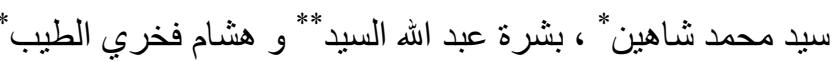

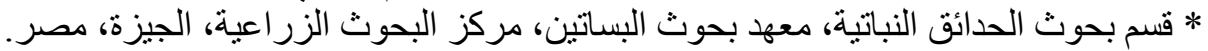

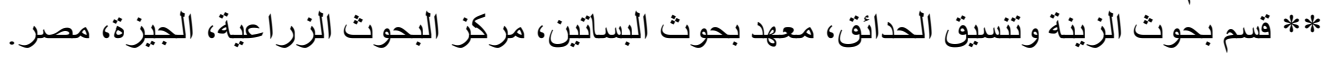

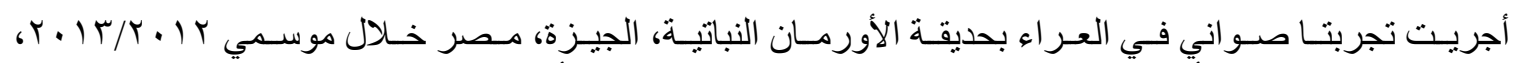

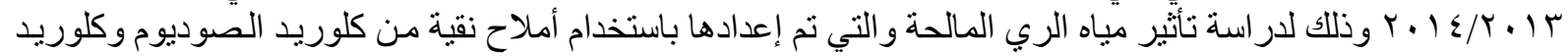

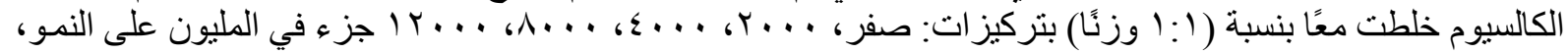

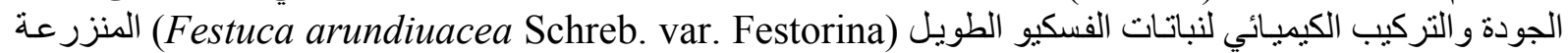

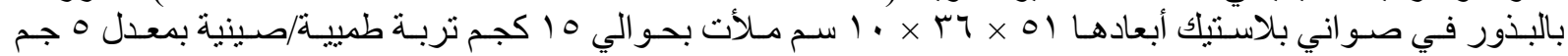
بذرة/صينية.

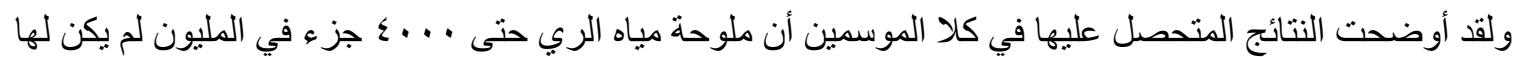

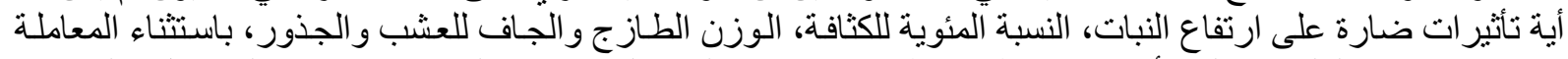

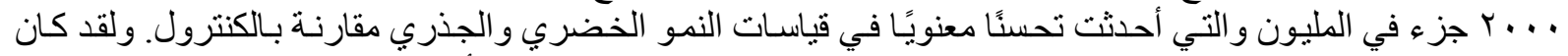

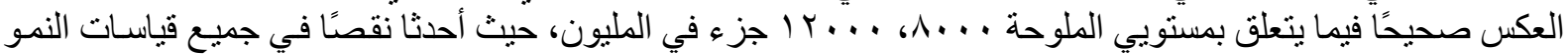

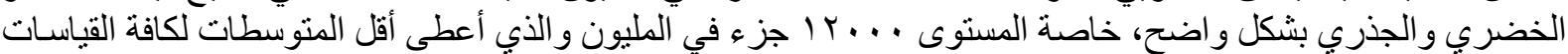

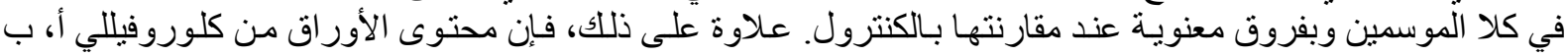

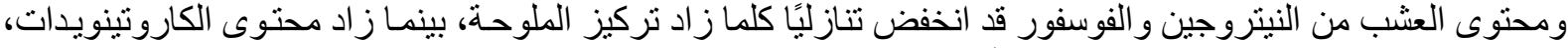
البوتاسيوم، الصوديوم، الكلوريد و الحمض الأميني برولين بشكل متصاعد كلما زاد الثنا مستوى الملوحة في مياه الري.

طبقَا لهذه النتائج، نستطيع القول بـأن مسطح الفسكيو الطويل (F. arundinacea Schreb. var. Festorina)

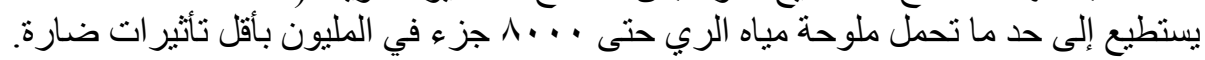

